\title{
MENURUNKAN PERILAKU ADHD DENGAN MELAKUKAN AKTIVITAS FISIK PADA ANAK USIA DINI
}

\section{Geraisa Dayura Chanet dan Adnani Budi Utami}

Universitas 17 Agustus 1945 Surabaya Jawa Timur, Indonesia

Email: geraisa13@gmail.com dan adnanibudiu@gmail.com

\section{Abstract}

The purpose of the study was to observe how to decrease ADHD reduction by doing physical activity in early childhood. The method in this study uses qualitative research design with single case experiement with intervention, namely physical activity such as swimming or karate and mentoring and counseling to parents and teachers. The intervention was carried out in swimming pools and subject schools for two weeks. Results obtained for two weeks, the subject can minimize difficult behavior focus, sitting still in class. Based on assessments conducted by observation method, interviews and psychological tests found that the subject had attention-attention-hyperactivity disorder (GPPH) or currently known as ADHD (attention deficit and hyperactivity disorder). The main feature of ADHD according to DSM V is that it often fails to pay attention, is careless, does not focus on when spoken to, often does not follow instructions in school, often leaves the seat while at school, cannot wait for the turn, always move and talk too much.

Keywords: developmental stage; early chilhood; adhd

\begin{abstract}
Abstrak
Tujuan penelitian adalah mengamati bagaimana menurunkan penurunan ADHD dengan melakukan aktivitas fisik pada anak usia dini. Metode dalam penelitian ini menggunakan desain penelitian kualitatif dengan desain kasus tunggal (single case experiement) dengan pemberian intervensi yaitu aktivitas fisik seperti olahraga berenang atau karate dan pendampingan serta konseling kepada orang tua dan guru. Pelaksanaan intervensi dilakukan di tempat renang dan sekolah subjek selama dua minggu. Hasil yang diperoleh selama dua minggu, subjek dapat meminimalkan perilaku sulit fokus, duduk diam di kelas. Berdasarkan asesmen yang dilakukan dengan metode observasi, wawancara dan tes psikologi ditemukan bahwa subjek memiliki gangguan pemusatan perhatian-hiperaktif impulsif (GPPH) atau saat ini dikenal dengan istilah ADHD (attention deficit and hyperactivity disorder). Ciri utama ADHD menurut DSM V adalah sering gagal memberikan perhatian, ceroboh, tidak fokus pada saat diajak bicara, sering tidak mengikuti intruksi disekolah, sering meninggalkan tempat duduk saat disekolah, tidak dapat menunggu giliran, selalu bergerak dan berbicara terlalu banyak.
\end{abstract}

Kata kunci: tahap perkembangan; anak usia dini; ADHD 


\section{Pendahuluan}

Perkembangan sosial anak sangat tergantung pada individu anak, peran orang tua, dewasa lingkungan masyarakat dan termasuk Taman Kanak-kanak. Adapun yang dimaksud dengan perkembangan sosial anak adalah bagaimana anak usia dini berinteraksi dengan teman sebaya, orang dewasa dan masyarakat luas agar dapat menyesuaikan diri dengan baik sesuai apa yang diharapkan oleh bangsa dan negara (Mayar, 2013).

Usia dini disebut juga sebagai tahap perkembangan kritis atau usia emas (golden age). Pada tahap ini sebagian besar jaringan sel-sel otak berfungsi sebagai pengendali setiap aktivitas dan kualitas manusia. Dua tahun pertama kehidupan manusia sangat penting bagi perkembangan anak. Anak mulai mengembangkan kemampuan motorik indrawi, visual dan auditori yang distimulasi melalui lingkungan sekitarnya (Schunk, 2012).

Anak usia dini adalah seorang anak yang usianya belum memasuki suatu lembaga pendidikan formal seperti sekolah dasar (SD) dan biasanya mereka tetap tinggal di rumah atau mengikuti kegiatan dalam benntuk berbagai lembaga pendidikan prasekolah, seperti kelompok bermain, taman kanak-kanak, atau taman penitipan anak. Anak usia dini adalah anak yang berusia 0-8 tahun (Nurmalitasari, 2015).

Masa anak usia dini merupakan masa keemasan. Pada masa ini anak mengalami perkembangan cepat. Anak mengalami proses perubahan perilaku dari tidak matang menjadimatang, dari sederhana menjadi kompleks, suatu proses evolusi manusia dari ketergantungan menjadi makhluk dewasa yang mandiri. Anak akan belajar menguasai tingkat yang lebih tinggi dari aspek-aspek gerakan, berpikir, perasaan dan interaksi baik dengan sesama maupun dengan benda-benda dalam lingkungan hidupnya (Holis, 2017).

Pendidikan anak usia dini ditunjukan kepada anak usia 0 sampai 6 tahun. Pendidikan anak usia dini bertujuan untuk memberikan stimulus pertumbuhan dan perkembangan agar lebih berkembang dengan baik dan siap menuju tahap pendidikan selanjutnya. Aspek perkembangan pada anak usia dini antara lain fisik-motorik, kognitif, sosio emosional, dan bahasa Santrock dalam (Rahman, 2009). Salah satu aspek perkembangan yang harus dikembangkan dalam pembelajaran anak usia dini yaitu aspek sosio emosional.

Pendidikan anak usia dini saat ini berkembang dengan pesat, hal itu didasari oleh harapan pemerintah Republik Indonesia untuk memperbaiki kualitas sumber daya manusia di masa mendatang. Pada ulang tahun Republik Indonesia ke 100 tahun diharapkan kualitas sumber daya manusia setara atau bahkan melebihi kualitas sumber daya manusia negara-negara maju (Suryana, 2013).

Menurut (Nadzirah, 2017) yang dimaksud anak ADHD yaitu anak yang mengalami gangguan konsentrasi untuk menerima pelajaran dari gurunya, terutama ketidakmampuan untuk memfokuskan dan menjaga perhatiannya pada satu hal. Beberapa perilaku yang nampak seperti; cenderung bertindak ceroboh, mudah tersinggung, lupa pelajaran sekolah dan tugas rumah, kesulitan mengerjakan tugas disekolah maupun dirumah, kesulitan dalam menyimak, kesulitan dalam menjalankan 
beberapa perintah, melamun, sering keceplosan dalam berbicara, tidak memiliki kesabaran yang tinggi, sering membuat gaduh, berbelit-belit dalam berbicara, dan suka memotong serta ikut campur pembicaraan orang lain adalah bentuk perilaku umum lainnya yang menjadi ciri khas $A D H D$. Selain itu mereka juga cenderung bergerak terus secara konstan dan tidak bisa tenang.

Attention deficit hyperactivity disorder (ADHD) merupakan salah satu kelainan perkembangan terbanyak pada masa anak dan dapat berlangsung sampai masa remaja dan dewasa (Susanto \& Sengkey, 2016). ADHD memiliki suatu pola yang menetap dari kurangnya perhatian dan atau hiperaktivitas, yang lebih sering dan lebih berat bila dibandingkan dengan anak lain pada taraf perkembangan yang sama. Biasanya didapatkan ciri-ciri ADHD ini pada dua atau lebih situasi yang berbeda seperti di rumah, di sekolah, dan di tempat kerja. Anak dengan ADHD selalu memiliki tiga komponen ciri utama yang sama yaitu inattention, impulsivity, dan hyperactivity.

Kesulitan dengan perhatian dapat menyebabkan mereka banyak kesulitan di kelas termasuk masalah mempertahankan perhatian selama mengerjakan tugas, memperhatikan detail, dan lupa tempat menyimpan barang yang diperlukan untuk penyelesaian tugas (Jennifer dkk, 2014). Seringkali, anak-anak dengan presentasi ini ADHD dipandang sebagai agresif dan mengganggu anak-anak lain dan staf pendidikan. Faktor yang berpengaruh terhadap munculnya $A D H D$ menurut faron dkk dalam MIF (Baihaqi \& Sugiarmin, 2006) yaitu, a) Genetik, Satu pertiga dari anggota keluarga $A D H D$ memiliki gangguan, yaitu jika orang tua mengalami $A D H D$, maka anaknya beresiko $A D H D$ sebesar $60 \%$. Pada anak kembar, jika salah satu mengalami $A D H D$, maka saudaranya 70-80\% juga beresiko mengalami ADHD. Pada studi gen khusus beberapa penemuan menunjukkan bahwa molekul genetika gen-gen tertentu dapat menyebabkan munculnya $A D H D$. b) Neurobiologis, temuan melalui MRI (pemeriksaan otak dengan teknologi tinggi) menunjukkan ada ketidaknormalan pada bagian otak depan. Bagian ini meliputi korteks prefrontal yang saling berhubungan dengan bagian dalam bawah korteks serebral secara kolektif dikenal sebagai basal ganglia. Bagian otak ini berhubungan dengan atensi, fungsi eksekutif, penundaan respons, dan organisasi respons. Kerusakan-kerusakan daerah ini memunculkan ciri-ciri pada ADHD. Menurut (Mujiman dan Munawar, 1997) mengidentifikasikan sebagai berikut: anak dengan gejala hiperaktif tidak dapat duduk diam, banyak ulah, mengganggu ketenangan dan tentunya sulit untuk berkonsentrasi. Ia sering mendapatkan hukuman atau teguran dari guru. Begitu pula halnya dengan lingkungan orang tuanya, di rumah sering mengganggu orang lain, malas belajar maunya main terus. Tentunya ia akan sering mendapatkan teguran atau kena marah, orang tua secara tidak sadar akan membandingkan dengan saudaranya yang lain atau anak lain. Sebagai akibatnya anak merasakan stress, merasa ditolak oleh orang tuanya. Hal ini dapat menimbulkan perasaan bahwa dirinya bodoh, jelek tidak seperti anak lain. Semangat belajar menurun bahkan dapat berkembmang menjadi perasaan benci pada pelajaran sekolah.

Orang tua memiliki peran penting dalam membimbing dan mendampingi anakanaknya baik dalam pendidikan formal maupun non-formal. Peran orang tua itu sendiri 
dapat mempengaruhi perkembangan anak dalam aspek kognitif, efektif dan psikmotor. Peran orang tua dalam penanganan perilaku hiperaktif anak (Hatimah, 2016). ADHD sangat penting karena anak $A D H D$ membutuhkan penanganan terutama perhatian yang khusus jika dibandingkan dengan anak-anak normal lainnya, baik dalam belajar maupun bersosialisasi (Erinta \& Budiani, 2012). Perkembangan anak hiperaktif akan lebih optimal apabila mereka mendapatkan tempat istimewa dan sesuai pula dimana mereka akan mendapatkan perlakuan yang nyaman dengan penanganan yang tepat oleh peran tenaga-tenaga pendidik yang khusus menangani gangguan ini. Selain itu keluarga adalah lingkungan yang utama bagi anak $A D H D$ khususnya orang tua karena peran orang tua dalam memfasilitasi mensupport dan mengarahkan anak $A D H D$ dalam memahami dan menjalani kehidupannya sangatlah penting (Prasasti \& WAHYUNI, 2018). Anak $A D H D$ membutuhkan bantuan dan pengertian dari orang-orang disekitar kita khususnya orang tua (Sari, 2016).

Berdasarkan observasi yang dilakukan di kelas B TK al-zaitun waru sidoarjo ditemukan bahwa ada salah satu siswa yang tidak dapat duduk tenang, kurang fokus dan kurang bersosialisasi dengan sekitar. Hal tersebut ditandai dengan observasi selama di sekolah dan informasi yang diberikan oleh guru serta orang tua. Berdasarkan observasi awal diketahui bahwa penyebab belum optimal adalah kurangnya kedisiplinan pola asuh orang tua di rumah.

Salah satu upaya untuk menurunkan perilaku ADHD pada anak dengan memberikan kegiatan yang lebih produktif dan merubah jadwal kegiatan harian dengan memberikan poster sebagai panduan di rumah.

\section{Metode Penelitian}

Pendekatan yang digunakan adalah pendekatan kualitatif. Pendekatan kualitatif yaitu metode penelitian yang terbentuk dari uraian kata-kata untuk dikumpulkan kemudian dilakukan analisis guna mendapatkan bahan penulisan yang otentik (Aiman, 2016). Menurut pendekatan secara kualitatif merupakan prosedur penelitian yang menghasilkan data deskriptif berupa kata-kata tertulis atau lisan dari orang-orang dan perilaku yang dapat diamati. Tipe penelitian ini merupakan studi kasus, sehingga penelitian dilakukan karena ketertarikan atau kepedulian pada suatu kasus khusus.

Untuk mendukung dan mendapatkan data dalam penelitian, peneliti menggunakan observasi, wawancara dan tes psikologi. teknik observasi yang digunakan adalah observasi partisipan, dimana peneliti turut ambil bagian dalam perikehidupan. Pengamatan partisipatoris memungkinkan peneliti dapat berkomunikasi secara akrab dan leluasa, sehingga memungkinkan untuk bertanya secara lebih rinci dan detail (Rahayu, 2004).

Alat observasi yang digunakan adalah anecdotal, pencatatan perilaku dilakukan sesegera mungkin pada tingkah laku anak, peneliti mencatat secara teliti apa dan bagaimana perilaku anak terjadi di sekolah.

Teknik wawancara yang digunakan adalah semi-structured interviews, peneliti menggunakan wawancara yang dibuat berupa daftar pertanyaan, tetapi tidak berupa 
kalimat-kalimat yang permanen (mengikat), dalam wawancara ini peneliti membawa kerangka-kerangka pertanyaan untuk disajikan kepada significant others yaitu orangtua, guru, maupun subjek sendiri (Rahayu, 2004).

Tes psikologi hanya dapat diberikan tes CPM, karena subjek tidak dapat menjalankan tes Binet dengan baik. Subjek berjenis kelamin perempuan berusia 6 tahun yang sedang berada di TK B.

Intervensi yang dilakukan dengan memberikan aktivitas fisik seperti olahraga atau tarian untuk menurunkan intensitas perilaku hiperaktif, dan memberikan jadwal kegiatan harian dirumah, guna membantu orang tua dan subjek dalam mendisiplinkan kegiatan d rumah. Intervensi juga di berikan kepada orang tua dan guru dengan konseling.

\section{Hasil dan Pembahasan}

Subjek memiliki kecerdasan dalam kategori rata-rata, sehingga subjek mampu dengan mudah merima pelajaran yang diberikan oleh guru di sekolah. Sehingga hasil selama enam kali pertemuan subjek hanya dapat melakukan aktivitas tersebut selama 2 kali pertemuan, dikarenakan orang tua yang kurang dapat melaksanakan kegiatan yang telah disepakati. Namun dari hasil kegiatan tersebut subjek terlihat mudah lelah dan merasa mengantuk, sehingga subjek dapat mengikuti pelajaran dengan baik dan mengikuti perintah guru.

\section{Kesimpulan}

Berdasarkan asesmen yang dilakukan dengan metode observasi, wawancara dan tes psikologi ditemukan bahwa subjek memiliki gangguan pemusatan perhatianhiperaktif impulsif (GPPH) atau saat ini dikenal dengan istilah ADHD (attention deficit and hyperactivity disorder). Ciri utama ADHD menurut DSM V adalah sering gagal memberikan perhatian, ceroboh, tidak fokus pada saat diajak bicara, sering tidak mengikuti intruksi disekolah, sering meninggalkan tempat duduk saat disekolah, tidak dapat menunggu giliran, selalu bergerak dan berbicara terlalu banyak.

Penyebab $A D H D$ secara pasti belum diketahui, namun beberapa penelitian mengatakan bahwa ketidaknormalan neurokimia yang menyebabkan $A D H D$. Dalam kasus subjek, bahwa kondisi tersebut dipaparkan oleh factor lingkungan, yaitu pola asuh orang tua, modelling terhadap perilaku, jadwal kegiatan yang tidak konsisten, sehingga berpengaruh pada proses perkembangan.

Agar subjek dapat terbantu dalam proses belajar dan mengembangkan diri, intervensi yang dilakukan adalah dengan melakukan kegiatan yang produktif, yaitu olahraga yang menyenangkan, seperti berenang atau bela diri. Hal ini bertujuan agar subjek merasa kelelahan dan diharapkan untuk tidur lebih awal dari biasanya dan dapat mengikuti pelajaran dengan baik didalam kelas. 


\section{BIBLIOGRAFI}

Aiman, Ummu. (2016). Evaluasi pelaksanaan penilaian autentik kurikulum 2013. Jurnal Pendidikan Madrasah, 1, 115-122.

Baihaqi, M. I. F., \& Sugiarmin, M. (2006). Memahami dan membantu anak ADHD. Bandung: PT. Refika Aditama.

Erinta, Deyla, \& Budiani, Meita Santi. (2012). Efektivitas penerapan terapi permainan sosialisasi untuk menurunkan perilaku impulsif pada anak dengan attention deficit hyperactive disorder (ADHD). Jurnal Psikologi Teori Dan Terapan, 3(1), 67-78.

Hatimah, Ihat. (2016). Keterlibatan keluarga dalam kegiatan di sekolah dalam perspektif kemitraan. Pedagogia, 14(2).

Holis, Ade. (2017). Peranan Keluarga/Orang Tua Dan Sekolah Dalam Mengembangkan Kreativitas Anak Usia Dini. Jurnal Pendidikan UNIGA, 1(1), 22-43.

Jennifer dkk. (2014). Implications for School Counselors. Georgia School Counselors Association Journal.

Mayar, Farida. (2013). Perkembangan sosial anak usia dini sebagai bibit untuk masa depan bangsa. Al-Ta Lim Journal, 20(3), 459-464.

Mujiman dan Munawar. (1997). Disfungsi Minimal Otak.

Nadzirah, Nuning. (2017). Konseling Integratif dalam Menangani Gangguan Konsentrasi Belajar pada Anak Adhd (Attention Deficit Hyperactivity Disorder). Jurnal Intelektual: Jurnal Pendidikan Dan Studi Keislaman, 7(1).

Nurmalitasari, Femmi. (2015). Perkembangan sosial emosi pada anak usia prasekolah. Buletin Psikologi, 23(2), 103-111.

Prasasti, Suci, \& Wahyuni, Heni. (2018). Peran Orang Tua Dalam Penanganan Anak Hiperaktif. Jurnal Ilmiah Konseling, 18(2).

Rahayu, I. T. \&. Ardani T. .. (2004). Observasi dan Wawancara.

Rahman, Ulfiani. (2009). Karakteristik perkembangan anak usia dini. Lentera Pendidikan: Jurnal Ilmu Tarbiyah Dan Keguruan, 12(1), 46-57.

Sari, Novika. (2016). Pola Pelaksanaan Bimbingan dan Konseling untuk Mengoptimalkan Kemampuan Anak Autis di Sekolah Dasar. JBKI (Jurnal Bimbingan Konseling Indonesia), 1(2), 31-35.

Schunk, Dale H. (2012). Learning theories an educational perspective sixth edition. Pearson. 
Menurunkan Perilaku ADHD dengan Melakukan Aktivitas Fisik pada Anak Usia Dini

Suryana, Dadan. (2013). Pendidikan Anak Usia Dini: Teori Dan Praktik Pembelajaran.

Susanto, Bayu D., \& Sengkey, Lidwina S. (2016). Diagnosis dan penanganan rehabilitasi medik pada anak dengan Attention Deficit Hyperactivity Disorder. Jurnal Biomedik: JBM, 8(3). 